\title{
Creating and maintaining play connection in a toddler peer group
}

\author{
Pursi, Annukka
}

Springer

2020

Pursi , A \& Lipponen , L 2020 , Creating and maintaining play connection in a toddler peer group . in A Ridgway, G Quinones \& L Li (eds), Peer Play and Relationships in Early Childhood : International Research Perspectives . International Perspectives on Early Childhood Education and Development, vol. 30 , Springer , Cham , pp. 93-111 . https://doi.org/10.1007/978-3-030-4

http://hdl.handle.net/10138/318601

https://doi.org/10.1007/978-3-030-42331-5_7

unspecified

acceptedVersion

Downloaded from Helda, University of Helsinki institutional repository.

This is an electronic reprint of the original article.

This reprint may differ from the original in pagination and typographic detail.

Please cite the original version. 


\title{
Chapter 7:
}

\section{Creating and Maintaining Play Connection in a Toddler Peer Group}

\author{
Annukka Pursi and Lasse Lipponen, \\ University of Helsinki, Faculty of Educational Sciences, Helsinki, Finland
}

\begin{abstract}
This study explores how one and two year old peers (henceforth toddlers) participate in joint play activities in a natural group-care setting. We focus on joint play activity between three toddler peers during one full day-care day in a Finnish toddler classroom. Questions guiding the analysis concern the sequential understanding of how play emerges within peer interaction and how toddler peers are able to build sustained co-participation in their joint play during the day. The analysis showed that joint play was fragmented and organized in short segments of dyadic or triadic interaction. Reestablishments of joint play and accumulation of significant play signals during the day were important practices for toddlers to constitute social organization and sustained co-participation in their multi-party peer play. The results strengthen our understanding of very young children as both more and less competent play companions in their peer groups and guide adults' practice in relation to peer play in toddler classrooms.
\end{abstract}

Keywords: play; joint activity; peer interaction; co-participation; toddler

\subsection{Introduction}

Peer relations and joint play in toddler peer groups are well acknowledged, described and valued in recent early childhood education (ECE) research (Harrison \& Sumsion, 2014; Johansson \& White, 2011; Li, Quinones \& Ridgway, 2017; Rayna \& Laevers, 2011; White \& Dalli, 2017). Empirical video-observation studies have produced detailed descriptions of joint play themes and patterns in toddler peer groups (e.g., Engdahl, 2011; Ridgway, Li, \& Quiñones, 2016). Studies have also informed us of the playful routines that toddlers produce and share in interaction with peers (Corsaro \& Molinari, 1990; Løkken, 2000), and thereby constructed knowledge of toddler's own peer play culture in ECE settings.

For toddlers, attaining and sustaining joint play interaction with peers calls for a rather sophisticated use of a range of interactional resources and practices, such as focusing and sharing attention, as well as observing, emulating, repeating and co-coordinating simple movement patterns, vocalizations and gestures in concert with each other (Engdahl, 2011; Farver, 1992; Løkken, 2000; Stambak \& Verba, 1986). Also, managing disputes, problem conduct (e.g. pushing, hitting, hair pulling, taking toys from others) and other interaction trouble (e.g. trouble with availability, trouble with understanding) in 
peer groups demands special kinds of social competences such as emotion regulation and ability to re-establish shared understanding (Kidwell, 2009, 2013; Singer \& Hännikäinen, 2002).

A large body of research has investigated the aforementioned interactional resources and practices as characterizations of toddlers' individual competences during play activities. However, considerably less attention has been given to the interactional organization of these play competences in situ in a multi-party context (Björk-Willén, 2007). This kind of sequential understanding in multi-party play situations is important in order to learn more about when, how and in what ways toddlers use these competences. For example, 1) how they actually maintain the progression of their joint play in the moment-to-moment unfolding flow of peer interaction, 2) build togetherness in their play activity, and 3) secure solidarity in their play group (Gunnarsdottir \& Bateman, 2017). The present study contributes to this line of research by analyzing systematic interactional features of joint play activity among three toddlers during one full day-care day. More specifically, we attempt to answer the following research questions:

1. How do the three focus children create and maintain their joint play interaction?

2. How do the three focus children build sustained co-participation in their joint play during the day?

\subsection{Methodological considerations}

\subsubsection{Context of the study and creation of data sources}

The article offers an analysis of a full day-care day from the perspective of three toddlers and their joint play activity during the period. With this particular focus, our aim is to explore in detail the complexities of peer interaction and explicate the interactional strategies of the focus children in making the play situations what they become. Our primary data consist of 28 videotaped sequences of dyadic and triadic joint play between the focus children. This video corpus is part of a larger ethnographic doctoral study examining play culture, and especially adults and children joint play activity in a Finnish toddler classroom ${ }^{1}$. Table 7.1 outlines the data and the creation of data sources in more detail.

\footnotetext{
${ }^{1}$ This particular toddler classroom is a municipal group-care setting for 13 children under the age of three with one kindergarten teacher, two nursery nurses and one personal assistant for a child with special needs. The day-care center is located in an outer suburb of Helsinki, Finland.
} 
Table 7.1. Creation of data sources

\begin{tabular}{|c|c|c|c|c|}
\hline & $\begin{array}{l}\text { Fieldwork } \\
\text { 2013-2016 }\end{array}$ & $\begin{array}{l}\text { Single case analysis } \\
\text { April 19, } 2016 \\
\text { 9:13-9:17 a.m. }\end{array}$ & $\begin{array}{l}\text { Full day video- } \\
\text { observation } \\
\text { April 19, } 2016 \\
\text { 8:00 a.m-3:45 p.m. }\end{array}$ & $\begin{array}{l}\text { Joint play activity } \\
\text { between three toddlers } \\
\text { April 19, } 2016\end{array}$ \\
\hline $\begin{array}{l}\text { Corpus of } \\
\text { data }\end{array}$ & $\begin{array}{l}\mathbf{1 5 0} \text { h of video- } \\
\text { observations } \\
\text { ( } 38 \text { days of full-day } \\
\text { observations) }\end{array}$ & $\begin{array}{l}3 \mathbf{m i n} 34 \text { sec } \\
\text { joint play activity } \\
\text { between three toddler } \\
\text { peers during small- } \\
\text { group playtime }\end{array}$ & $\begin{array}{l}\text { 2h } 40 \text { min } 05 \text { sec } \\
\text { Video-observation }\end{array}$ & $\begin{array}{l}34 \text { min } 09 \text { sec } \\
\text { A total of } 28 \text { joint play } \\
\text { sequences between } \\
\text { three toddlers. Selection } \\
\text { of all the dyadic as well } \\
\text { as triadic playful } \\
\text { encounters. }\end{array}$ \\
\hline $\begin{array}{l}\text { Analytical } \\
\text { questions }\end{array}$ & $\begin{array}{l}\text { What is going on? } \\
\text { Is there play in the } \\
\text { interaction? } \\
\text { If yes, the camera } \\
\text { records it. }\end{array}$ & $\begin{array}{l}\text { How is joint play } \\
\text { activity created and } \\
\text { maintained during the } \\
\text { selected sequence? }\end{array}$ & $\begin{array}{l}\text { What happened } \\
\text { before the selected } \\
\text { case and what } \\
\text { followed after it } \\
\text { between the three } \\
\text { toddlers? }\end{array}$ & $\begin{array}{l}\text { How is joint play } \\
\text { activity created, } \\
\text { maintained and re- } \\
\text { established during the } \\
\text { day between the three } \\
\text { focus children? }\end{array}$ \\
\hline $\begin{array}{l}\text { Sequential } \\
\text { approach }\end{array}$ & $\begin{array}{l}\text { Sampling for this } \\
\text { study: Sequences in } \\
\text { which at least three } \\
\text { toddlers are mutually } \\
\text { engaged in joint play } \\
\text { activity without } \\
\text { adults involved. }\end{array}$ & $\begin{array}{l}\text { Verbal descriptions, } \\
\text { detailed transcripts } \\
\text { and sequential } \\
\text { analysis of joint play } \\
\text { activity } \\
\text { (Sequences } 2,3,4,5 \text { ) }\end{array}$ & $\begin{array}{l}\text { Sampling for the } \\
\text { analysis: Sequences } \\
\text { in which the three } \\
\text { focus children are } \\
\text { mutually engaged in } \\
\text { joint play activity } \\
\text { without adults } \\
\text { involved. }\end{array}$ & $\begin{array}{l}\text { Narrative descriptions, } \\
\text { detailed transcripts and } \\
\text { sequential analysis of } \\
\text { joint play activity } \\
\text { (a sub-corpus of seven } \\
\text { sequences is analyzed } \\
\text { in this paper) }\end{array}$ \\
\hline
\end{tabular}

At the beginning of the study, the teacher of the group informed all the families about the proposed video-observation research and their right not to participate. In accordance with contemporary ethical guidelines at University of Helsinki (Finnish Advisory Board on Research Integrity), informed consent was sought from parents, ECE practitioners, the director of the daycare center and municipal officials. During the data collection period, the researcher was a non-participant observer, intending to disrupt the everyday life of the group as little as possible (Løkken, 2011). As the video-observation method and long-term fieldwork raised specific ethical considerations, careful attention was paid to the situated ethics (for a more detailed description of ethical considerations, see Pursi \& Lipponen, 2018).

\subsubsection{Ethnographic context of peer play activity}

The three toddlers in our study were Venla (1 year 6 months old girl), Niilo (1 year 9 months old boy) and Ella (2 years 2 months old girl) ${ }^{2}$. During the data collection period, they had been together in the

\footnotetext{
${ }^{2}$ All the names are pseudonyms.
} 
same toddler classroom for three months. When observing different kinds of play situations during the field work (joint play between peers, play alone, parallel play, play between adults and children), some weekly occurring play patterns gradually began to catch the researcher's attention. Once a week 3-4 children (typically the three youngest and sometimes one older child as well) had an opportunity to stay indoors for a longer time (20-30 min) than usual with one adult, while the others began their transition to outdoor activity. During that small-group playtime, guided play was organized by an adult (typically physical activity play involving large play objects such as ramps, tunnels, mattresses and sofas), and sometimes this small group had an opportunity to play freely without adult guidance. What made these situations (both guided play as well as free play) special was the intensity and longevity of joint play between the peers (as seen in chapter 2). This small group had the whole classroom space to themselves and there were no competing activities in the surroundings. The selected day for the present analysis was one of these days when the three toddlers Venla, Niilo and Ella remained indoors and were able to play freely without adult guidance and without presence of the whole group.

\subsection{Data analysis}

In our analysis, we drew mainly on the sequential perspective of conversation analysis (CA) and its treatment of joint activity, co-participation and play (Bateman, 2015; Goodwin, 2007). In CA analytical interest focuses exclusively on those aspects of play that the interactants make publicly available. The basic assumption is that play actions are lodged in the sequential organization of unfolding interaction and therefore cannot be examined in isolation from their interactional context (i.e. previous, current and following turns at talk/embodied interaction). The questions guiding our analysis concerned understanding how play actions are constructed and responded to in situ by relying on different verbal and non-verbal interactional resources and turn-taking practices (Bateman, 2015; Goodwin, 2000). We illustrate our analysis by combining verbal descriptions, frame grabs and transcriptions.

Our observations indicated that the joint play among our focus children was fragmented and organized in short segments of dyadic or triadic interaction (14 sec $-4 \mathrm{~min} 16 \mathrm{sec}$ ). The observations also revealed that interruptions and re-establishments of joint play were common features of peer play among the children. Thereby, a relevant scope of our analysis was the sequences in which participants created and maintained their joint play (subsection 7.3.1), managed to re-establish joint play after interactional problems (subsection 7.3.2) and repeated significant play actions over and over again during the day (subsection 7.3.3). The backbone of our analysis was one play episode during the free 
play time in the morning when Ella, Niilo and Venla had a chance to stay indoors for a longer period of time while the others began their transition to the outdoors. This particular play episode provided a great opportunity to elaborate on the triggering event of triadic play, progression of the sustained joint play (a total of $2 \mathrm{~min}$, one of the longest sequence of the triadic play) as well as problem-remedy sequences, since these all occurred in quick succession.

In the following sequences, transcription conventions are used based on Jefferson (2004).

[

$\uparrow \downarrow$

:

WORD

${ }^{\circ}$ word ${ }^{\circ}$

$£$

(.)

$(())$
Brackets indicate overlapping talk/nonverbal actions

Arrows indicate shifts into especially high or low pitch

Sound or nonverbal act before colon is stretched

Loud volume

Quiet voice relative to the surrounding talk

Smiley voice

Micropause

Words in double brackets are descriptions of nonverbal actions.

\subsubsection{Creating and maintaining play connection in the peer group}

Through play signals (Bateson, 1976), players communicate their playful stance to others in order to initiate and maintain joint play activity. Play connection (Pursi \& Lipponen, 2018) occurs between participants when the recipients of the play signal display alignment with the play activity and affiliation with the player's stance. According to our use of analytical terminology, affiliation relates to the affective or action level (e.g., emotional display, play actions), and alignment to the structural level (e.g., an attentional display, body orientation, gaze direction) of joint activity (Stivers, 2008). To reveal the systematic ways in which joint play activity was managed between our three focus children during the day, it was logical to initially look at how the play began. This was done by discerning the very first play signaling sequences and identifying how the focus children relied on different verbal and non-verbal interactional resources in order to 1) make play actions observable and recognizable to one another and 2) build alignment and affiliation (play connection).

\section{Sequence 1: Dyadic play connection between Ella and Niilo}


The very first sequence of joint play (Table 7.2) emerged during the free play time after breakfast. At this point Ella began to move around the classroom, calling for Niilo (line 1) and the following brief moment of play connection was co-produced.

Table 7.2. Sequence 1: Dyadic play connection between Ella and Niilo

\begin{tabular}{|l|l|l|}
\hline & Transcription and verbal description of interaction & Sequential analysis \\
\hline 1 & $\begin{array}{l}\text { HEI NII:LO (.) NIILO:: } \\
\text { EEY NII:LO (.) NIILO:: ((runs around the classroom and looks for } \\
\text { Niilo }))\end{array}$ & Attracting attention \\
\hline $\begin{array}{l}\text { Niilo: } \\
\text { open })) \\
{[((\text { while getting closer starts to laugh)) }}\end{array}$ & $\begin{array}{l}\text { [(smiles, quickly changes direction and starts to run away from } \\
\text { Niilo)) }\end{array}$ & $\begin{array}{l}\text { Play connection: Alignment and } \\
\text { affiliation with Niilo's playful } \\
\text { stance }\end{array}$ \\
\hline 3 \\
Ella:
\end{tabular}

Ella initiated contact by calling for Niilo by name and in this way demonstrated her interest in interaction with Niilo in particular. Niilo's response in line 2 (approaching and smiling) displayed a positive emotional stance (affiliation) towards Ella. When Niilo got closer, his smile escalated into enthusiastic bursts of laughter. This exaggerated positive emotional stance could be interpreted as a play signal. The interpretation becomes validated in line 3 with Ella treating Niilo's response as an invitation to joint play. She aligned and affiliated with the idea of joint play by producing her own playful contribution. By smiling, turning around very fast and beginning to run in the opposite direction she was making a non-verbal suggestion of a chasing game. Niilo aligned with Ella's contribution and while running maintained the play connection with short bursts of laughter. Ella, on the other hand, maintained the play connection by checking behind her a few times while running to see if Niilo was still following her. Interruption of joint play occurs as Ella produces an explicit request for joint play with cars (line 6) and Niilo misaligns by orienting to the boy nearby. Lines 6-7 together show a trouble with availability (Kidwell, 2013) from Ella's perspective as Niilo engages in another play frame and in this way ignores Ella's play request. 


\section{Sequence 2: Triadic play connection between Ella, Niilo and Venla}

Re-establishment of joint play emerged 14 minutes after the first moment of play connection. At this point Venla also became part of the joint activity. Sequence 2 (Table 7.3 and Figure 7.1) began to develop as Ella, Niilo and Venla met in a larger playroom. Ella was approaching the play area where Niilo was playing alone with a doll carriage into which he was gathering small balls and Venla was standing next to a half-open window looking outside and rubbing the window glass. While approaching, Ella first observed Niilo and then Venla. Play connection between participants was established by producing reciprocal smiles, short bursts of laughter and simple body movements.

Table 7.3. Sequence 2: Triadic play connection between Ella, Niilo and Venla

\begin{tabular}{|c|c|c|}
\hline & Transcription and verbal description of the interaction & Sequential analysis \\
\hline 1 Ella: & Haha ((pushes doll carriage and approaches Venla $))$ & Play signaling \\
\hline 2 Venla: & $\begin{array}{l}\text { ((turns towards Ella and smiles, then continues rubbing the window } \\
\text { glass while still facing Ella)) }\end{array}$ & $\begin{array}{l}\text { Play connection: Alignment } \\
\text { and affiliation with Ella's } \\
\text { playful stance (Fig. 7.1.A.) }\end{array}$ \\
\hline 3 Ella: & Haha ((starts to turn the carriage towards Niilo $))$ & Play signaling \\
\hline 4 Niilo: & $\begin{array}{l}£ A:: h \text { ((gazes at and approaches Ella })) \\
{[£ h a:: h((\text { mutual gaze with Ella }))}\end{array}$ & $\begin{array}{l}\text { Play connection: Alignment } \\
\text { and Affiliation with Ella's } \\
\text { playful stance }\end{array}$ \\
\hline 5 Ella: & [Hahhahhuhhah ((gazes at Niilo with a grin $))$ & \multirow{2}{*}{$\begin{array}{l}\text { Heightened moment of play } \\
\text { connection between Ella and } \\
\text { Niilo (Fig. } 7.1 . B \text { ) }\end{array}$} \\
\hline 6 Venla: & $\begin{array}{l}\text { [((intensively observes others with a smiling face and keeping a finger } \\
\text { inside her mouth }))\end{array}$ & \\
\hline $\begin{array}{l}7 \text { Ella \& } \\
\text { Niilo: }\end{array}$ & $\begin{array}{l}\text { ((Ella and Niilo start to jump at the same time })) \\
{[((\text { while jumping they continue to produce short bursts of laughter }))}\end{array}$ & Maintaining play connection \\
\hline 8 Venla: & $\begin{array}{r}{[((\text { picks up a rattle from the floor and then approaches others }))} \\
{[((j u m p s \text { and shakes the rattle strongly with a smiling face }))}\end{array}$ & $\begin{array}{l}\text { Alignment and affiliation } \\
\text { with Ella's and Niilo's } \\
\text { playful stance }\end{array}$ \\
\hline $\begin{array}{l}9 \text { Ella \& } \\
\text { Niilo: }\end{array}$ & {$[(($ stop their movement and observe Venla $))$} & Joint attention shift \\
\hline $\begin{array}{l}10 \\
\text { Venla, } \\
\text { Ella } \\
\text { \& Niilo: }\end{array}$ & $\begin{array}{l}\text { (( smiling, laughing and jumping together)) } \\
\text { ((The triadic jumping is sustained for } 10 \text { sec, then Venla throws her } \\
\text { rattle away and shifts her attention to a baby doll on the floor and sits } \\
\text { down, Ella and Niilo observe Venla's activity shift and then return to } \\
\text { their joint jumping and laughing again)) }\end{array}$ & $\begin{array}{l}\text { Heightened moment of } \\
\text { triadic play connection } \\
\text { (Fig. 7.1.C) }\end{array}$ \\
\hline
\end{tabular}




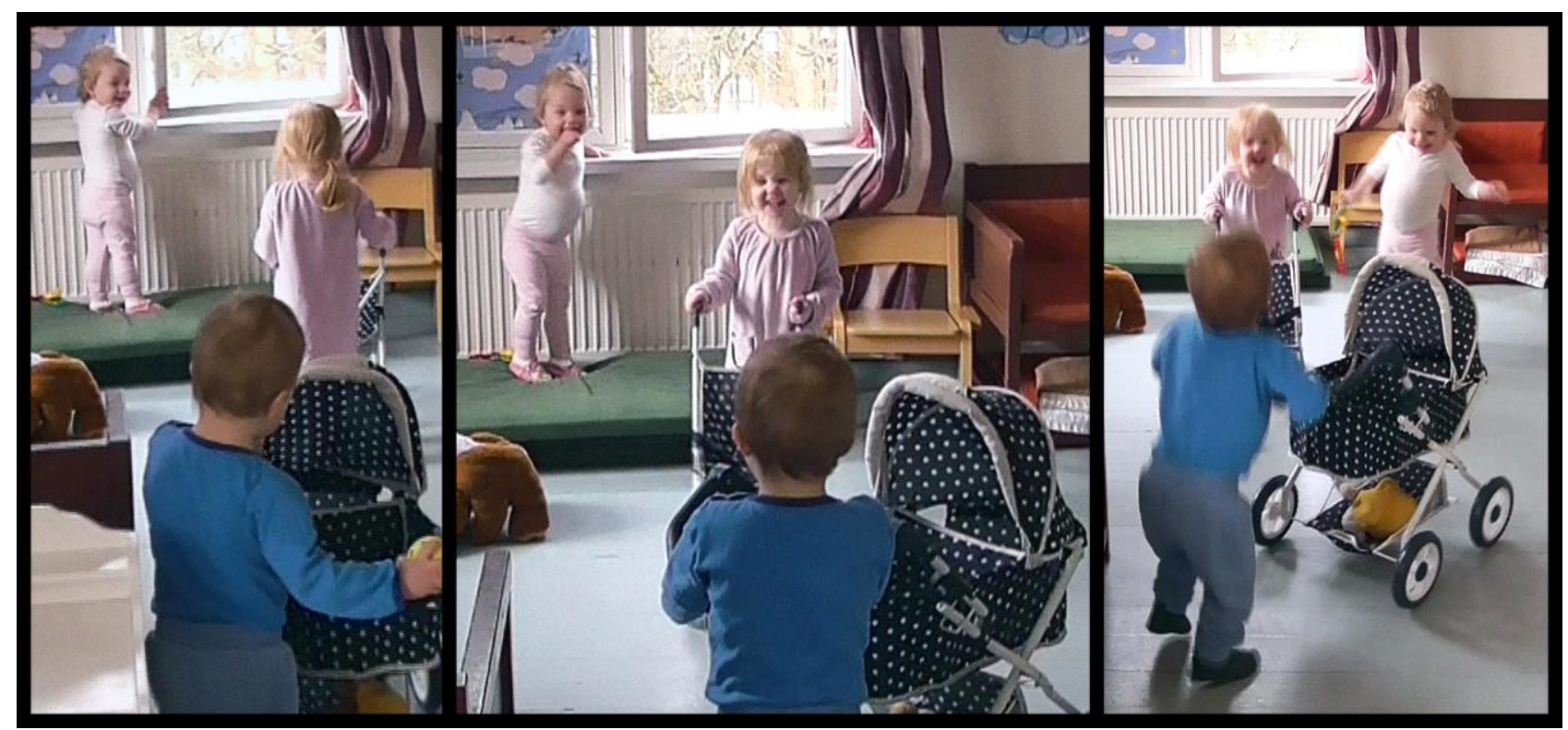

Figure 7.1. A) Play connection between Venla (the girl next to the window) and Ella (the girl in the middle), B) Venla witnesses play connection between Ella and Niilo (the boy in front), C) Joint laughter and jumping constitutes triadic play.

Sequence 2 illustrates how the toddlers were competent in using gestures, simple body movements, smiley vocalizations and laughter to create and maintain play connection. Triadic play connection was constituted by delicately timed play signals (short bursts of laughter, lines 1 and 3) and aligning and affiliating responses (mutual gaze and smiling/smiling vocalizations, lines 2 and 4) and maintained with co-coordinated gaze shifts and joyful repetition of gestures (laughter, smiling, vocalizations) and simple body movements. What followed was a sustained shared play interaction in which the moving toddlers' bodies were the main creators and objects of the joint play. These observations are in line with prior research describing how co-coordinated body movements and gestures are the core feature of playfulness during toddlerhood (the playful quality of toddling style, Løkken, 2000).

If we look more closely how Ella's, Niilo's and Venla's joint actions were organized, we can see that their body movements were highly reciprocal and even synchronous (jumping in line 7), indicating embodied attunement and heightened co-participation (Sidnell, 2009). With attuned and heightened moments of co-participation we mean intensive interactional sequences in which participants are displaying their shared playful stance in overlap (lines 7 and 10). Although these synchronous and reciprocal chains of triadic play actions were very brief $(10 \mathrm{sec})$ they can be seen as highly complex interactional accomplishments and meaningful signs of togetherness, sharing and friendship in peer group. These intensive moments constitute what Trevarthen and Delafield-Butt (2017) call a non- 
verbal narrative, the very first form of sustained joint play interaction with shared meaning and intersubjective understanding among pre-verbal children in a multi-party interactional context.

Sequence 2 also reveals how children with their reciprocal shifts of attention produce more subtle togetherness and an interactional space (Mondada, 2009) for multi-party engagements. This interactional space is created by using coordinated gaze shifts as interactional resources. This is evident e.g. in line 9 with Ella and Niilo stopping their movement at the same time and shifting their gaze toward approaching Venla. This same pattern was repeated in line 10 when Venla threw her rattle away and shifted her attention to a baby doll on the floor and Niilo's and Ella's attention followed. It seems that through these joint attention shifts Ella, Niilo and Venla were attuning to each other's actions and in this way produced togetherness and sharing. By creating an interactional space for Venla to first participate in the ongoing play and then leaving it for other activities, Ella and Niilo demonstrated that they were engaging in joint play with Venla and not just between themselves.

If we compare the interactional organization in sequence 1 and 2 we can see that Ella was the initiator of the contact in both sequences. It is interesting to compare Ella's use of different interactional resources. In sequence 2, Ella was non-verbal with her play signaling. She was not producing verbal requests or proposals for collaboration as in sequence 1. Rather, she created a play connection by simply beginning the activity (Stivers \& Sidnell, 2016). This strategy seemed to be an effective way to engage Niilo and Venla into joint play. A wider corpus of empirical interaction studies supports these observations. Engagement in joint play is typically established and maintained between preverbal and verbal toddlers (Björk-Willén, 2007) or between pre-verbal toddlers and adults (Bateman, 2015; Pursi \& Lipponen, 2018) by "doing play" actions and participation, not by "talking about play" and participation. Whereas older children more often begin and maintain their joint play by talking about play and by using requests (e.g., Can you X?) or proposals (e.g., Let's X; How about X; Should we X) for activity collaboration (Stivers \& Sidnell, 2016).

\subsubsection{Problem-remedy sequences in joint play}

In this subsection we describe how Ella, Venla and Niilo managed to re-establish play connection after different kinds of interactional problems during the day. In our analysis we provide three examples of problem-remedy sequences (3, 4 and 5) and one example of a sequence in which interactional problems remained unsolved (sequence 6). 


\section{Sequence 3: Progression of joint play after trouble with availability}

Sequence 3 (Table 7.4 and Figure 7.2) is a continuation of the heightened moment of triadic play connection described above. After moment of shared jumping the progression of joint play was suspended with Niilo shifting his attention to the handle of his doll carriage, Venla sitting down on the floor next to a baby doll and toy washtub, and Ella starting to push her doll carriage. Reestablishment of joint play connection began to develop as Ella tried to contribute to the joint play by shifting her body and gaze towards Niilo and making 'funny' sound with her mouth (line 1, Fig. 7.2.A). What followed was trouble with availability (Kidwell, 2013) as Niilo remained occupied with the handle of his carriage, only glancing quickly towards Ella before shifting his gaze back to the handle (line 2).

Table 7.4. Sequence 3: Progression of joint play after trouble with availability

\begin{tabular}{|c|c|c|}
\hline & Transcription and verbal description of interaction & Sequential analysis \\
\hline 1 Ella: & $\begin{array}{l}\text { [((turns her body and gaze towards Niilo and makes explosive } \\
\text { and 'funny' sound by forcing air out of her mouth with tongue } \\
\text { between lips }))\end{array}$ & $\begin{array}{l}\text { Contribution to the joint play and } \\
\text { attraction of other's attention } \\
\text { (Fig. 7.2.A) }\end{array}$ \\
\hline 2 Niilo: & $\begin{array}{l}\text { [((briefly glances at Ella and then shifts his gaze back to the } \\
\text { handle of his carriage }))\end{array}$ & $\begin{array}{l}\text { Trouble with availability: } \\
\text { Niilo misaligns with Ella's playful } \\
\text { stance and play contribution }\end{array}$ \\
\hline 3 Ella: & ((repeats the funny sound by increasing its force and duration)) & $\begin{array}{l}\text { First attempt to re-establish play } \\
\text { connection by repeating and } \\
\text { upgrading the same play action }\end{array}$ \\
\hline 4 Niilo: & $\begin{array}{l}\text { ((shifts her gaze to Ella, takes a deep breath and then produces } \\
\text { a slow and deep exhalation without any sound }))\end{array}$ & Alignment with minimal affiliation \\
\hline 5 Ella: & $\begin{array}{l}\text { Hah } \uparrow \text { hah } \uparrow \text { hah }((\text { gazes at Niilo })) \\
\uparrow \text { Aijaijaijaijai ((closes her eyes and turns her face up to the } \\
\text { ceiling })) \\
{\left[{ }^{\circ} \text { hahah } \downarrow^{\circ}((\text { returns her gaze towards Niilo }))\right.}\end{array}$ & $\begin{array}{l}\text { Second attempt to re-establish play } \\
\text { connection by modulating the play } \\
\text { action } \\
\text { (Fig. } 7.2 . B \text { ) }\end{array}$ \\
\hline 6 Niilo: & {$[(($ begins to jump $))$} & $\begin{array}{l}\text { Alignment and affiliation with } \\
\text { Ella's playful stance }\end{array}$ \\
\hline $\begin{array}{l}7 \text { Ella \& } \\
\text { Niilo: }\end{array}$ & ((shared jumping)) & Progression of joint play activity \\
\hline
\end{tabular}




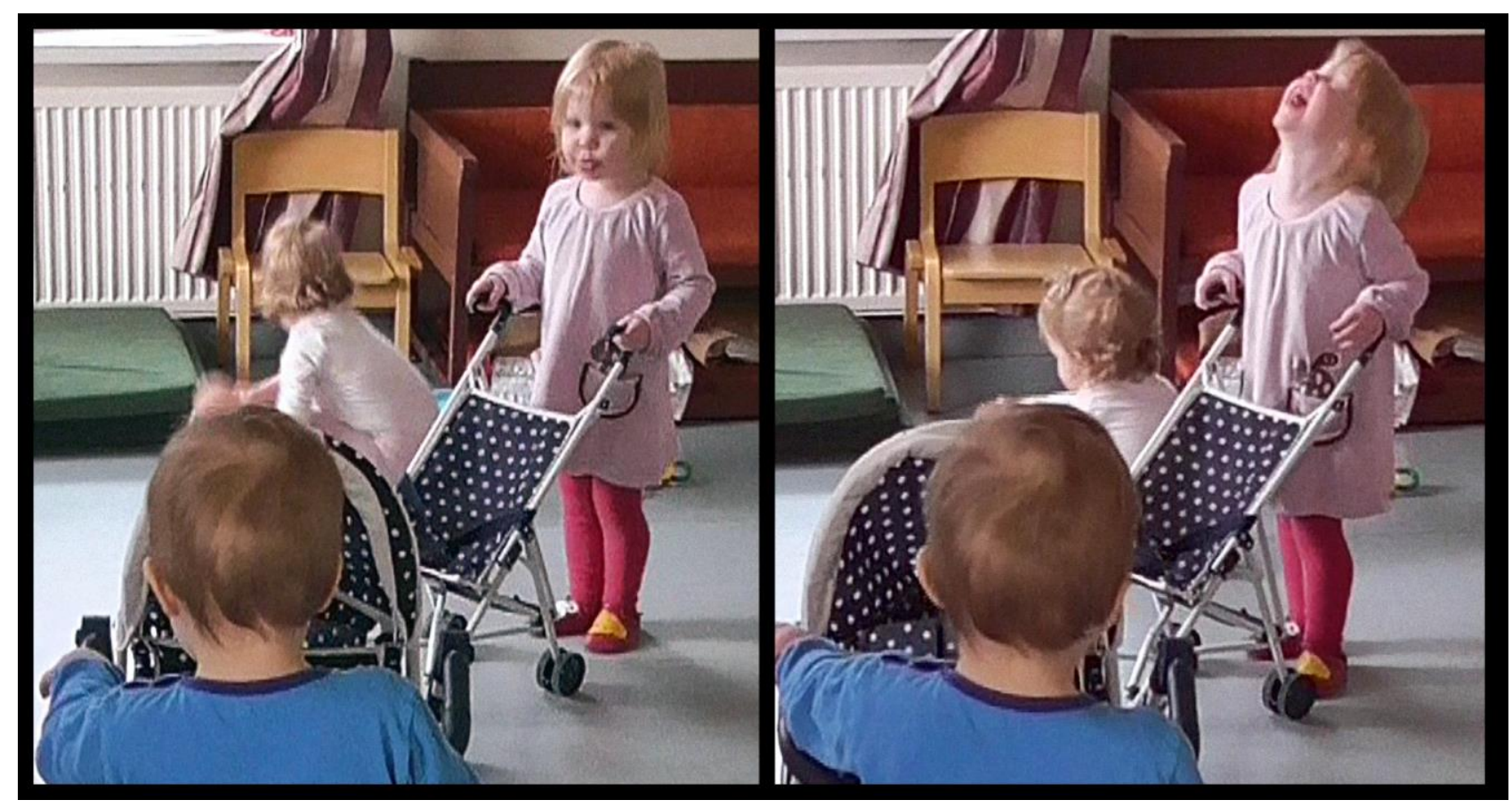

Figure 7.2. A) Ella's contribution to joint play, B) Escalated laughter as means to re-establish play connection

As we can see in lines 1 and 2, Ella's first attempt to contribute to the joint play did not re-establish the play connection with Niilo. In line 3 Ella increases the force and duration of her play action (blowing air out of her mouth more forcefully to produce a louder and longer sound). By repeating and upgrading the same play action she was trying to re-establish play connection (also see, Kidwell, 2013) and finally succeeded in attracting Niilo's undivided attention (line 4). Although Niilo aligned with Ella in line 4 by sharing a mutual gaze, he was not able to produce firm affiliation with Ella's play action (only a deep breath without a sound) and therefore the progression of joint play remained suspended. In line 5 (Fig. 7.2.B), Ella produced a second attempt to re-establish play connection by returning to laughter, one of the significant gestures of Ella's and Niilo's previous joint play. This time Niilo instantly responded by jumping (line 6), another significant gesture of their previous joint play. As a consequence, the play connection was successfully re-established and the progression of the joint play secured (line 7).

If we elaborate on this sequence more closely from the perspective of remedial work, we can see that it took multiple turns and demanded a lot of interactional work from Ella to re-establish the play connection with Niilo. This complex chain of actions: 1) new play contribution, 2) misalignment 3) repetition of the play contribution, 4) alignment with minimal affiliation, 5) modulation of play actions, and 6) firm alignment and affiliation, demonstrates that Ella was not producing these funny 
sounds to Niilo in order to secure interactional alignment but rather wanted to produce them with Niilo as joint play actions and was therefore building sustained co-participation and sharing (alignment and affiliation). As Niilo did not respond by actually engaging in these play actions (perhaps because the production of these funny sounds was quite challenging from the perspective of motor control for the somewhat younger Niilo), Ella redesigned her play actions so that Niilo would be able to actively participate.

Studies have demonstrated that adults also use this kind of interactional calibration in order to build sustained co-participation with toddlers in joint play (Pursi, Lipponen \& Sajaniemi, 2018). The core features of interactional calibration in play seems to be the flexible and situational modulation of one's participation between stance leading (new play contributions), stance following (careful alignment and affiliation with others' play actions) and leading by following (building on others' play actions). Ella was flexible with these different entities, not restricting to one of them alone. She constructed and modulated her participation turn by turn in its interactional context in order to produce heightened co-participation with Niilo.

\section{Sequences 4 and 5: Progression of play after problem conducts}

As our focus children's joint activity unfolded further we could observe another interruption of play connection in the form of problem conduct. Typically in toddler classrooms these problem-remedy sequences have to do with adults having children alter their problem conduct (e.g. pushing, hitting, hair pulling, taking toys from others) (Kidwell, 2013). In these situations, adults undertake quite extensive work to secure and maintain solidarity in the group and to guarantee the progression of interaction. Our observations show how the children in our study managed these situations in their peer group. Sequence 4 (Table 7.5 and Figure 7.3) demonstrates how Venla's problem conduct suspended the progression of play between all participants (lines 3-8).

Table 7.5. Sequence 4: Progression of play after problem conducts

\begin{tabular}{|l|l|l|}
\hline & Transcription and verbal description of interaction & Sequential analysis \\
\hline 1 Venla: & {$[($ shifts her gaze to Niilo and approaches Niilo's doll carriage $))$} & Activity shift \\
\hline 2 Ella: & $\begin{array}{l}\text { [hahhah hahhah ähah hah ((jumping and producing short burst of } \\
\text { laughter, sustaining her gaze towards Niilo and Venla }))\end{array}$ & $\begin{array}{l}\text { Attempt to re-establish play } \\
\text { connection with Venla and } \\
\text { Niilo }\end{array}$ \\
\hline $\begin{array}{l}\text { 3 Venla \& } \\
\text { Niilo: }\end{array}$ & $\begin{array}{l}\text { (both Niilo and Venla are now grabbing the inside of Niilo's doll } \\
\text { carriage) })\end{array}$ & $\begin{array}{l}\text { First trouble conduct (Fig. } \\
\mathbf{7 . 3 . A})\end{array}$ \\
\hline 4 Niilo: & $[$ a::.::((stressful vocalization $))$ & \\
\hline
\end{tabular}




\begin{tabular}{|c|c|c|}
\hline 5 Ella: & $\begin{array}{l}{[((\text { stops laughing, observes Venla and Niilo and puts a finger into }} \\
\text { her mouth with a slightly concerned facial expression }))\end{array}$ & $\begin{array}{l}\text { Aligning and affiliating with } \\
\text { Niilo's emotional stance } \\
\text { display }\end{array}$ \\
\hline 6 Venla: & ((picks up two balls from Niilo's carriage $))$ & \multirow{3}{*}{$\begin{array}{l}\text { Second trouble conduct } \\
\text { (Fig. 7.3.B) }\end{array}$} \\
\hline 7 Venla: & {$[(($ begins to run away with the balls in her hands $))$} & \\
\hline 8 Niilo: & $\begin{array}{l}\text { [A:::::::::::((repeats and upgrades the display of stressful } \\
\text { vocalization and simultaneously shifts his gaze to Venla)) }\end{array}$ & \\
\hline 9 Ella: & $\begin{array}{l}\text { [((gazes at Niilo with empathetic concern on her face, then shifts } \\
\text { her gaze to Venla }))\end{array}$ & $\begin{array}{l}\text { Ella's empathetic concern } \\
\text { (Fig. 7.3.C) }\end{array}$ \\
\hline
\end{tabular}

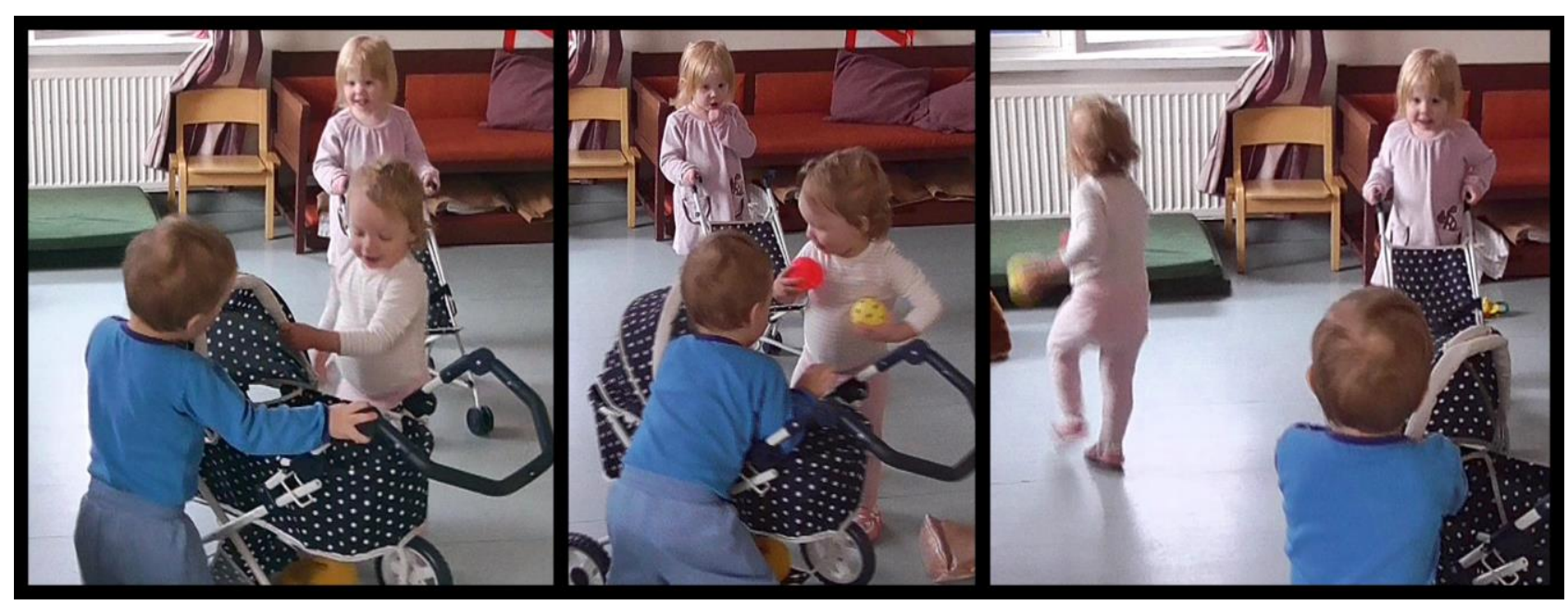

Figure 7.3. A) First problem conduct, B) Second problem conduct, C) Ella's empathetic concern

Lines 3-8 reveal that trouble emerges in the interaction between Venla and Niilo, as Niilo at first resisted Venla's approach by vocalizing stressfully (line 4) and then repeated and upgraded his negative emotional stance display in line 8 when Venla took two balls from his carriage (line 7, Fig. 7.3.B). Ella observed the development of this situation by shifting from laughing to a more serious emotional stance (Fig. 7.3.A $\rightarrow$ Fig. 7.3.B), by putting a finger into her mouth (Fig. 7.3.B) and by frowning during Niilo's stressful vocalizations (lines 5, 9, Fig. 7.3.C). Ella's responses to the situation indicate emotional stance shift from playful joy to empathic concern. Sequence 5 (Table 7.6 and Figure 7.4) reveals how this problem conduct was managed by the participants.

Table 7.6. Sequence 5: Progression of play after problem conducts

\begin{tabular}{|l|l|l|}
\hline & Transcription and verbal description of interaction & Sequential analysis \\
\hline 1 Venla: & $(($ climbs onto the sofa with balls in her hand $))$ & Problem conduct continues \\
\hline 2 Ella: & $[$ hah hah ((approaches Venla $))$ & $\begin{array}{l}\text { First attempt to re-establish play } \\
\text { connection }\end{array}$ \\
\hline 3 Niilo: & {$[(($ observes Venla and Ella $))$} & $\begin{array}{l}\text { Alignment with Venla's and Ella's } \\
\text { actions }\end{array}$ \\
\hline 4 Ella: & $\begin{array}{l}\uparrow \text { hah } \uparrow \text { hah }(.) \uparrow h a h \uparrow h \text { hah }((\text { while getting closer, } \text { extends her hands } \\
\text { towards the balls }))\end{array}$ & $\begin{array}{l}\text { Second attempt to re-establish } \\
\text { play connection }\end{array}$ \\
\hline
\end{tabular}




\begin{tabular}{|c|c|c|}
\hline & {$\left[{ }^{\circ}\right.$ hah hah ${ }^{\circ}(($ tries to take the balls from Venla $))$} & \\
\hline 5 Venla: & {$[(($ smiles and pulls her hands back $))$} & $\begin{array}{l}\text { Alignment and affiliation with } \\
\text { Ella's playful stance but } \\
\text { misalignment with other actions }\end{array}$ \\
\hline 6 Niilo: & {$[(($ observes the situation $))$} & $\begin{array}{l}\text { Alignment with Venla's and Ella's } \\
\text { actions }\end{array}$ \\
\hline 7 Ella: & $\begin{array}{l}\text { ((extends her face closer to Venla's face)) } \\
\text { [hihihihhahaijaijai }\end{array}$ & $\begin{array}{l}\text { Third attempt to re-establish play } \\
\text { connection } \\
\text { (Fig. 7.4.A) }\end{array}$ \\
\hline 8 Venla: & {$[(($ smiles with her mouth wide open $))$} & $\begin{array}{l}\text { Alignment and affiliation with } \\
\text { Ella's playful stance (Fig. 7.4.A) }\end{array}$ \\
\hline 9 Niilo: & $\begin{array}{l}{[((\text { shifts his attention to the carriage, grabs the inside of the }} \\
\text { carriage }))\end{array}$ & Misalignment and activity shift \\
\hline $\begin{array}{l}\text { 10 Venla } \\
\text { \& Ella: }\end{array}$ & $\begin{array}{l}\text { ((Venla smiles and hands the balls to Ella; Ella receives the } \\
\text { balls and turns away)) }\end{array}$ & $\begin{array}{l}\text { Moment of remedy } \\
\text { (Fig. 7.4.B) }\end{array}$ \\
\hline $\begin{array}{l}11 \text { Niilo, } \\
\text { Venla, } \\
\text { Ella: }\end{array}$ & $\begin{array}{l}\text { ((Niilo finds a plate from the carriage, approaches the home } \\
\text { play corner and begins to make food. Venla returns to her } \\
\text { previous activity next to the window. Ella begins play with the } \\
\text { balls by tapping them together and walking around the room.)) }\end{array}$ & Playing alone (Fig. 7.4.C) \\
\hline
\end{tabular}

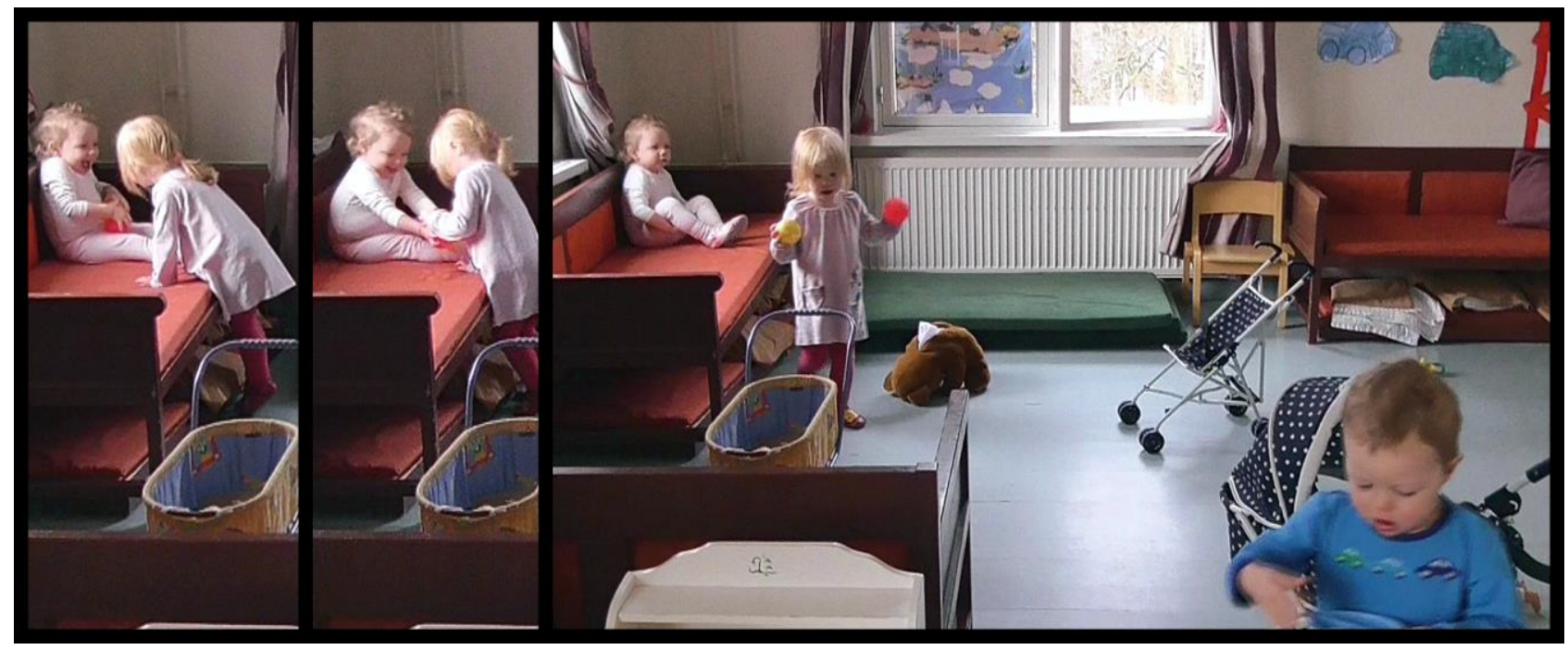

Figure 7.4. A) Ella's remedial work, B) Moment of remedy, C) Progression of play

Lines 1-7 reveal how Ella was able to produce successful solution to the interactional problem. Ella worked to re-establish play connection by producing small bursts of laughter while simultaneously approaching Venla. With these actions Ella was maintaining communicative concord and securing solidarity in the peer group, as she was marking Venla as a play companion regardless of the problematic conduct. A moment of remedy emerged as Venla cooperated and gave the balls to Ella (line 10) and Niilo found another activity (lines 9, 11) and in this way managed to overcome the disappointment that Vela's actions had caused. It seems that this problem conduct was small enough for our focus children to manage by themselves. Therefore, it provided an important training ground 
for how to manage interactional problems and re-establish play connection in a peer group. However, this does not mean that these children were competent enough to solve all of their conflicts. The situation would have been very different if e.g. Niilo would have searched for an adult with his gaze or escalated his negative emotional display (e.g. by crying), therefore showing that he would not have been able to manage the situation by himself (c.f. Kidwell, 2009, 2013). In this kind of situation Ella's and Venla's interaction would probably also have unfolded differently.

\section{Sequence 6: Interactional problems remain unsolved}

Sequence 6 (Table 7.7 and Figure 7.5) reveals how efforts at remedial work sometimes fail. In this sequence joint play turned into trouble with availability and finally into wistful longing during afternoon free playtime.

Table 7.7. Sequence 6: Interactional problems remain unsolved

\begin{tabular}{|c|c|c|}
\hline & Transcription and verbal description of interaction & Sequential analysis \\
\hline 1: & ((Venla, Niilo and Ella playing with toy cars side by side $))$ & Joint and parallel play (Fig 7.5 A.) \\
\hline 2 Venla: & ((distances herself from the others $))$ & Misalignment \\
\hline 3 Niilo: & $\begin{array}{l}\text { ((shifts his gaze towards Venla })) \\
\text { Ah:: ((points and sustains gaze toward Venla for several } \\
\text { seconds }))\end{array}$ & $\begin{array}{l}\text { First attempt to re-establish play } \\
\text { connection }\end{array}$ \\
\hline 4 Venla: & $\begin{array}{l}\text { ((first gazes at Niilo and then shifts her gaze toward other } \\
\text { children nearby }))\end{array}$ & Misalignment \\
\hline 5 Niilo: & $\begin{array}{l}\text { Eh:: ((sustains his gaze towards Venla, then points towards Ella } \\
\text { and shifts his gaze from Venla to Ella)) }\end{array}$ & $\begin{array}{l}\text { Second attempt to re-establish } \\
\text { play connection (Fig. } 7.5 . \mathrm{B})\end{array}$ \\
\hline 6 Venla: & ((walks towards the other children $))$ & Misalignment \\
\hline 7 Niilo: & $\begin{array}{l}\text { ((walks toward Ella, then turns around and sustains his gaze } \\
\text { towards Venla for several seconds with face slowly tilting } \\
\text { down }))\end{array}$ & $\begin{array}{l}\text { Third attempt to re-establish play } \\
\text { connection (Fig.7.5.C) }\end{array}$ \\
\hline
\end{tabular}

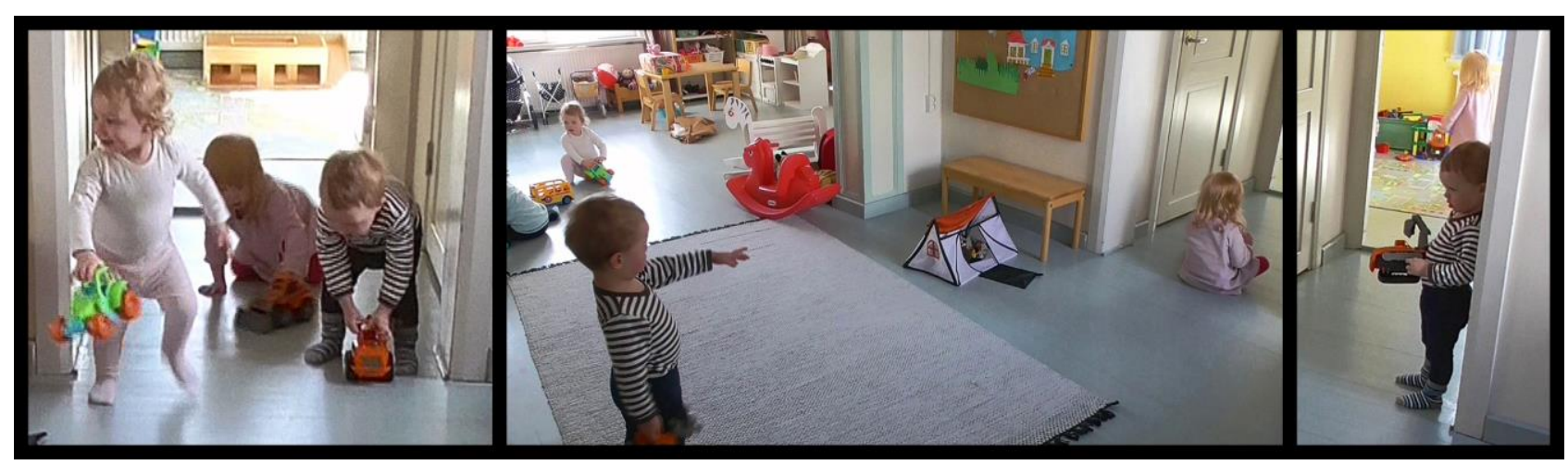

Figure 7.5. A) Joint and parallel play, B) Attempt to re-establish play connection, C) Attempt to reestablish play connection turns into wistful longing 
The sequential organization of Niilo's actions reveal that he was using multiple interactional strategies to signal to Venla that he was willing to continue joint play in a multi-party context. Niilo's first attempt to re-establish play connection was a combination of vocalization (“Ah::”), pointing and a sustained gaze toward Venla. As Venla misaligned by shifting her gaze toward other children nearby, Niilo then produced a second attempt by combining the vocalization ("Eh::"), pointing gesture and gaze shift from Venla to Ella (Fig. 7.5.B), as if to say: "Hey, our joint play is over here." As Venla was not responding, Niilo began to walk towards Ella, then stopped and oriented his body towards Venla again and sustained his gaze firmly at Venla for several seconds. This was Niilo's third attempt to re-establish play connection. After several seconds of sustained gaze towards Venla, Niilo's intensive and demanding gaze began to shift into wistful longing (Fig. 7.5.C).

This sequence revealed how complex and demanding the re-establishment of joint play can be for pre-verbal children in a natural group-care setting where multiple competing activities are occurring simultaneously. From Niilo's perspective, the multiple efforts to re-establish play connection indicate that for him the progression of triadic joint play would have been very important. The wistful longing was further evidence of it. This sequence also reveals that toddlers are more and less competent play companions in their peer group and that their competence is always related to the situational organization of interaction (Kalliala, 2014).

\subsubsection{Accumulation of play signals during the day}

In this section, we draw together our observations from the perspective of our second research question: How do the three focus children build sustained co-participation in their joint play during the day? Although Ella, Niilo and Venla were not able to build long-lasting storylines in their joint play, they co-constructed meaningful play signals that became significant gestures of their joint play. They also used these same significant play signals in new situations and accumulated different play signals together (e.g. by integrating jumping, requesting, laughing and coordinated gaze shifts into their play signaling turns). The first shared interactional resources for the joint play were smiling, laughing, co-coordinated gaze shifts and jumping. These play actions became significant gestures of the joint play between all three participants. Some interactional resources, e.g. verbal requests ("come Niilo"), were used only by Ella. Interestingly, Ella's verbal play proposals and requests were not so effective in the establishment of play connections in the peer group. 


\section{Sequence 7: Accumulating significant play signals during the day}

To give an example of the accumulation of play signals, we provide sequence 7 (Table 7.8) which describes a dyadic encounter between Ella and Niilo during the morning free playtime after multiple dyadic and triadic joint play episodes with shared smiling, laughter, jumping. Ella's play signalling in lines 4 and 6 demonstrates the accumulative use of significant play signals as she integrates jumping, requesting, laughing and coordinated gaze shifts into her playful communication.

Table 7.8. Sequence 7: Accumulating significant play signals during the day

\begin{tabular}{|c|c|c|}
\hline & Transcription and verbal description of interaction & Sequential analysis \\
\hline $\begin{array}{l}1 \text { Ella } \\
\& \\
\text { Niilo: }\end{array}$ & $\begin{array}{l}\text { ((parallel play with blocs; both children are sitting on the floor } \\
\text { side by side but engaging in their own doings without sharing } \\
\text { looks or co-coordinated actions etc. }))\end{array}$ & $\begin{array}{l}\text { Incongruent alignment and } \\
\text { affiliation }\end{array}$ \\
\hline 2 Ella: & $\begin{array}{l}\text { ((Ella stands up from the floor and then gazes at Niilo })) \\
\text { [Tule Niilo } \\
\text { [Come Niilo }\end{array}$ & $\begin{array}{l}\text { Attracting attention and } \\
\text { requesting for collaboration }\end{array}$ \\
\hline 3 Niilo: & {$[(($ shifts his gaze towards Ella $))$} & Alignment without affiliation \\
\hline 4 Ella: & $\begin{array}{l}\text { ((turns her back and begins to jump, then turns around and gazes } \\
\text { at Niilo again)) } \\
\text { [Tule Niilo (.) hyppimään } \\
\text { [Come now Niilo (.) let's jump ((bends and extends her knees } \\
\text { rhythmically as if to demonstrate the jumping movement }))\end{array}$ & $\begin{array}{l}\text { Play signalling and request for } \\
\text { collaboration }\end{array}$ \\
\hline 5 Niilo: & {$[(($ sustains his gaze towards Ella $))$} & Alignment without affiliation \\
\hline 6 Ella: & ((turns around, begins to jump and produces escalated laughter $)$ ) & $\begin{array}{l}\text { Second attempt to establish play } \\
\text { connection }\end{array}$ \\
\hline 7 Niilo: & ((stands up, follows Ella and produces bursts of laughter $))$ & $\begin{array}{l}\text { Play connection: Alignment and } \\
\text { affiliation with Ella's play signals }\end{array}$ \\
\hline
\end{tabular}

Another relevant aspect of building sustained co-participation in peer play was the way children were able to re-establish play connection after interruptions and interactional problems. As we mentioned before joint play among our focus children was fragmented and organized into short segments (14 $\mathrm{sec}-4 \mathrm{~min} 16 \mathrm{sec}$ ) during the day. Especially Niilo's and Venla's attention was shifting from one activity to another and sometimes quite extensive interactional work (by Ella) was needed to reestablish the play connection and ensure the progression of the joint play. Short bursts of laughter and co-coordinated gaze shifts seemed to be the most frequent interactional practices that our focus children used to maintain and re-establish their play connection in different situations. In addition, laughter was effective interactional resource for settling both troubles with availability as well as problem conducts. Overall, it seems that both re-establishments of play connection and accumulation of significant play signals were important practices for toddlers to constitute social organization and sustained co-participation in their peer group. When these significant play signals were repeated and 
integrated together during the day in different situations, sustained non-verbal narratives emerged between participants (Trevarthen \& Delafield-Butt, 2017).

\subsection{Conclusion}

The present in-depth analysis of young children's joint play activities in a multi-party context during one full day-care day contributes to further understanding how very young children are able to organize their action in concert with each other in order to build shared understanding and sustained co-participation in their peer groups. On the one hand, the analysis revealed how emerging social competence is put into practice, and on the other, how very young children despite these social competences need support and guidance in their peer play. The findings have profound implications for early childhood education practice, as they strengthen our understanding of very young children as both more and less competent play companions in their peer groups (Kalliala, 2014). In educational research and pedagogical practice, we cannot emphasize the more competent and ignore the less competent interactional features of the toddling style. Rather, we need to develop theoretical, methodological as well as pedagogical frameworks that consider both aspects at the same time in their situational contexts.

From the pedagogical perspective, this study opened up a set of interactional themes and questions that could guide adults' practice in relation to peer play. In order to facilitate and enhance toddlers' peer play in group care settings, it is important for adults to understand when, how and in what ways children: 1) make play signals to each other, 2) establish heightened moments of play connection, 3 ) re-establish play connection after interruptions and interactional problems and 4) accumulate meaningful play signals together in different situations during the day. We strongly think that, when adults are able to observe and identify these phenomena from the flow of interaction (such as chapter 6 , this volume), they are also more skillful to provide delicately timed and designed guidance and support for the children when needed.

\section{Acknowledgments}

We wish to thank first of all Venla, Niilo and Ella for their playful moments that inspired this work. We are also thankful to all the parents and ECE practitioners for their cooperation. For comments and discussions we are most grateful to Marjatta Kalliala and Nina Sajaniemi. 


\section{References}

Bateman, A. (2015). Conversation Analysis and Early Childhood Education: The co-production of knowledge and relationships (Doing pretend play, 4) (pp. 41-66). Hampshire: Ashgate/ Routledge.

Bateson, G. (1976). A theory of play and fantasy. In J. S. Bruner, A. Jolly, \& K. Sylva (Eds.), Play - Its role in development and evolution (pp. 119-129). Harmondsworth: Penguin Books Ltd.

Björk-Willén, P. (2007). Participation in multilingual preschool play: Shadowing and crossing as interactional resources. Journal of Pragmatics, 39, 2133-2158.

Corsaro, W. A. \& Molinari, L. (1990). From seggiolini to discussione: the generation and extension of peer culture among Italian preschool children. International Journal of Qualitative Studies in Education, 3(3), 213-230.

Engdahl, I. (2011). Toddler interaction during play in the Swedish preschool. Early Development and Care, 181(10), 1421-1439.

Farver, J. A. M. (1992). Communicating shared meaning in social pretend play. Early Childhood Research Quarterly, 7, 501-516.

Goodwin, C. (2000). Action and embodiment within situated human interaction. Journal of Pragmatics, 32(10), 1489-1522.

Goodwin, C. (2007). Participation, stance and affect in the organization of activities. Discourse \& Society, 18, 53-73.

Gunnarsdottir, B. \& Bateman, A. (2017). Toddler agency and conversation analysis. Early Childhood Folio, 21(1), 33-38.

Harrison, L. J., \& Sumsion, J. (2014). Lived Spaces of Infant-Toddler Education and Care. Exploring Diverse Perspectives on Theory, Research and Practice. Dordrecht: Springer.

Jefferson, G. (2004). Glossary of transcript symbols with an introduction. In G. H. Lerner (Ed.), Conversation analysis. Studies from the first generation (pp.13-31). Amsterdam: John Benjamins.

Johansson, E., \& White, E. J. (2011). Educational Research with Our Youngest. Voices of Infants and Toddlers. The Netherlands: Springer.

Kalliala, M. (2014). Toddlers as both more and less competent social actors in Finnish day care centres. Early Years, 34(1), 4-17.

Kidwell, M. (2009). Gaze shifts as an interactional resource for very young children. Discourse Processes, 46, 145-160.

Kidwell, M. (2013). Availability as a trouble source in directive-response sequences. In M.

Hayashi, G. Raymond, \& J. Sidnell (Eds.), Conversational Repair and Human Understanding (pp. 234-260). Cambridge: Cambridge University Press.

Løkken, G. (2000). The playful quality of the toddling "style". International Journal of Qualitative Studies in Education, 13(5), 531-542.

Løkken, G. (2011). Lived experience as an observer among toddlers. In E. Johansson, \& E. J. White (Eds.), Educational Research with our Youngest: Voices of Infants and Toddlers (pp. 161184). Dordrecht: Springer Science. 
Mondada, L. (2009). Emergent focused interactions in public places: A systematic analysis of the multimodal achievements of a common interactional space. Journal of Pragmatics, 41(10), 1977-1997.

Pursi, A. \& Lipponen, L. (2018). Constituting play connection with very young children: Adults' active participation in play. Learning, Culture and Social Interaction, 17, 21-37.

Pursi, A., Lipponen, L., \& Sajaniemi, N. (2018). Emotional and playful stance taking in joint play between adults and very young children. Learning, Culture and Social Interaction, 18, 28-45.

Rayna, S. \& Laevers, F. (2011). Understanding children from 0 to 3 years of age and its implications for education. What's new on the babies' side? Origins and evolutions. European Early Childhood Education Research Journal, 19(2), 161-172.

Ridgway, A., Li, L., \& Quiñones, G. (2016). Visual narrative methodology in educational research with babies: Triadic play in babies' room. The Video Journal of Education and Pedagogy $(V J E P)$ : Springer Open Journal.

Sidnell, J. (2009). Participation. In S. D'hondt, J.-O. Ostman, \& J. Verschueren (Eds.), The pragmatics of interaction (pp.125-156). Amsterdam: John Benjamins.

Singer, E., \& Hännikäinen, M. (2002). The Teacher's Role in Territorial Conflicts of 2- to 3-YearOld Children. Journal of Research in Childhood Education, 17(1), 5-18.

Stambak, M., \& Verba, M. (1986). Organization of social play among toddlers: An ecological approach. In E. Mueller, \& C. Cooper (Eds.), Peer relations: Process and outcome (pp. 229247). Orlando, FL: Academic.

Stivers, T. (2008). Stance, Alignment, and Affiliation During Storytelling: When Nodding Is a Token of Affiliation, Research on Language and Social Interaction, 41(1), 31-57.

Stivers, T. \& Sidnell, J. (2016). Proposals for activity collaboration. Research on Language and Social Interaction, 49(2), 148-166.

Trevarthen, C., \& Delafield-Butt, J. (2017). Intersubjectivity in the imagination and feeling of the infant: Implications for education in the early years. In J. White, \& C. Dalli (Eds.), Underthree years olds in policy and practice (pp. 17-40). Singapore: Springer. 